JURNAL BASICEDU

Research \& Learning in Elementary Education

https://jbasic.org/index.php/basicedu

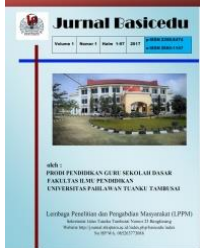

\title{
PENGEMBANGAN BAHAN AJAR MEMBACA PERMULAAN DENGAN MENGGUNAKAN CERITA FABEL PADA SISWA SEKOLAH DASAR
}

\author{
Reni Gustiawati ${ }^{1}$, Darnis Arief ${ }^{2,}$ Ahmad Zikri $^{3}$ \\ Universitas Negeri Padang, Sumatera Barat, Indonesia
}

E-mail: Reni2121@gmail.com, darnisarief@fip.unp.ac.id, mailto: zikria79@yahoo.com²

\begin{abstract}
Abstrak
Penelitian ini bertujuan untuk menghasilkan proses pengembangan bahan ajar membaca permulaan dan menghasilkan bahan ajar membaca permulaan dengan menggunakan cerita Fabel untuk pendidik kelas II yang valid, praktis, dan efektif. Penelitian ini menggunakan penelitian pengembangan berdasarkan model 4D (Define, Design, Develop dan Disseminate). Kevalitan dapat dilhat dari validasi isi, bahasa, penyajian, kegrafikaan dan RPP, keseluruhan 93.10\% dengan kategori sangar valid. Pratikalitas bahan ajar dilihat dari respon pendidik, $98.92 \%$ respon peserta didik 96.15\% sedangkan efektifitas Membaca permulaan persentase $100 \%$. Dapat disimpulkan bahwa bahan ajar membaca permulaan menggunakan cerita Fabel yang dikembangkan layak digunakan dalam membaca permulaan di kelas II SD.
\end{abstract}

Kata Kunci: Bahan Ajar, Fabel, Membaca Permulaan

\begin{abstract}
This study aims to produce a process of developing beginning reading teaching materials and producing beginning reading teaching materials using Fable stories for valid, practical, and effective Class II educators. This study uses development research using the 4D model (Define, Design, Develop and Disseminate). Validity can be seen from the validation of content, language, presentation, graphic and lesson plans, overall $93.10 \%$ with a very frightening category. Teaching material is seen from the response of educators, $98.92 \%$ of students $96.15 \%$ while the effectiveness of the initial reading percentage of $100 \%$. Can solve reading teaching materials using Fable stories that were developed are suitable to be used in beginning reading in grade II elementary school.
\end{abstract}

Keywords: Teaching Material, Fable, Beginning Reading

@ Jurnal Basicedu Prodi PGSD FIP UPTT 2020

$\triangle$ Corresponding author :

Address :-

Email : -

ISSN 2580-3735 (Media Cetak)

Phone 
355 Pengembangan bahan ajar membaca permulaan dengan menggunakan cerita fable pada siswa sekolah dasar-Reni Gustiawati, Darnis Arief, Ahmad Zikri

\section{PENDAHULUAN}

Bahan ajar yang digunakan pada proses pembelajaran sesuai dengan kurikulum yang berlaku. Bahan ajar penting dalam proses pembelajaran. Pentingnya bahan ajar antara lain: (1) merupakan alat bantu guru dalam pembelajaran, (2) bahan ajar dapat menarik perhatian siswa dalam pembeajaran karena memiliki desain dan gambar yang menarik, (3) bahan ajar juga cara inovatif guru dalam mengembangkan pembelajaran dengan berbagai karakteristik siswa, (4) bahan ajar penting sebagai referensi guru dalam memperbaiki pembelajaran yang selanjutnya (Lestariningsih \& Suardiman, 2017). Akan tetapi, bahan ajar ajar yang di gunakan belum menggambarkan pentingnya bahan ajar itu digunakan.

Mata pelajaran yang perlu diperhatikan dalam pengembangan bahan ajar salah satunya adalah Bahasa Indonesia. Pembelajaran bahasa Indonesia memuat empat kerampilan berbahasa, yaitu mendengarkan, berbicara, membaca, dan menulis (Irawati \& Elmubarok, 2015). Namun, membaca merupakan salah satu keterampilan berbahasa yang sangat penting di samping tiga keterampilan berbahasa lainnya. Hal ini didasarkan karena membaca merupakan sarana untuk mempelajari suatu hal sehingga bisa memperluas pengetahuan dan menggali pesan-pesan tertulis dalam bahan bacaan. Walaupun demikian, membaca bukanlah suatu pekerjaan yang mudah untuk dilakukan dan perlu bimbingan melalui proses pembelajaran yang tepat.

Membaca adalah kegiatan sehari-hari yang sering kita lakukan secara sadar atau tidak sadar melalui penguraian pesan yang mengelilingi kita dalam berbagai bentuk. Membaca adalah proses yang kompleks yang melibatkan berbagai keterampilan (Whitehurt dan Lonigan dalam $\mathrm{Al}$ Akremi, 2016:2) daripada decoding pesan sederhana. Menurut Tampubolon (2008:5) membaca merupakan suatu proses menerjemahkan simbol tulis ke dalam bunyi bahasa yang diubah menjadi lambang tulisan dan bunyi-bunyi. Pembelajaran membaca bukan semata-mata dilakukan agar peserta didik mampu membaca. Proses pembelajaran membaca memuat banyak kegiatan yang dapat dilakukan pada peserta didik, seperti kegiatan memprediksi teks bacaan, menanggapi teks bacaan, menceritakan kembali secara lisan maupun tulisan, dan lain sebagainya. Dengan demikian dapat disimpulkan bahwa pengembangan bahan ajar membaca merupakan merupakan salah satu faktor penentu keberhasilan sebuah proses pembelajaran.

Kenyataan di lapangan berdasarkan observasi penulis lakukan pada guru kelas SDN 13 Lolong Padang, diperoleh informasi bahwa, (1) bahan ajar membaca permulaan dengan menggunakan dongeng belum di kembangkan, (2) Guru memiliki keinginan untuk menciptakan bahan ajar sendiri, namun keterbatasan waktu dan keterbatasan sarana membuat guru belum bisa mengembangkan bahan ajar, (3). Karakteristik siswa kelas 2 yang cendrung menyukai dongeng bergambar akan tetapi guru kurang menerapkan dongeng di kelas, (4) Dongeng yang di gunakan menggunakan teks yang panjang sehingga anak menjadi tidak tertarik. Hal demikian berdampak terhadap ketidaktercapaian tujuan pembelajaran sebagaimana harusnya.

Siswa kelas rendah, khususnya kelas dua SD lebih senang bermain daripada disuruh untuk duduk membaca, sehingga guru harus memfasilitasi pembelajaran dengan bermain sambil belajar. Siswa cenderung lebih menyukai buku yang memiliki banyak gambar dan warna yang menarik (Annisarti Siregar dan Elva Rahmah, 2016:11). Sementara buku dongeng yang di gunakan di sekolah memiliki warna yang beragam dan teks bacaan dongeng terlalu panjang sehingga 
siswa tidak tertarik untuk membaca (Ade Asih Susiari Tantri dan I Putu Mas Dewantara, 2017: 204).

Mengatasi permasalahan di atas, perlu dilakukan pengembangan bahan ajar membaca yang menunjang keterampilan membaca siswa sesuai kriteria penyusunan bahan ajar, sehingga perlu membuat buku pendamping buku siswa. Hal ini diperlukan karena buku siswa hanya memuat aktivitas belajar dan minim dalam menjelaskan materi pelajaran. Pengembangan bahan ajar yang baik haruslah memuat pengetahuan (fakta, konsep, prinsip, prosedur), keterampilan/ kemampuan, dan sikap yang harus dipelajari siswa dalam mencapai tujuan pembelajaran (Depdiknas, 2007: 4). Selain itu, bahan ajar yang dikembangkan harus mengikuti perkembangan ilmu pengetahuan dan perkembangan zaman agar dapat memberikan ilmu yang terbarukan dan pengetahuan terkini sehingga bisa diterapkan siswa dalam kehidupannya.

Bahan ajar dapat dikembangkan dengan adanya kreatifitas guru, seperti menciptakan buku penunjang yang menarik dengan karakter binatang dan dapat mengajak siswa berimajinasi. Bahan ajar yang dapat digunakan dalam pembelajaran memiliki beragam jenis dan bentuk. Salah satu jenisnya ialah buku cerita fabel yang merupakan buku dua dimensi yang memiliki beragam unsur sehingga menimbulkan daya fikir pada anak (Hafiidh, Bahruddin, \& Aziz, 2016). Fable dipilih karena merupakan bahan ajar berbentuk buku cerita yang dianggap mempunyai daya tarik tersendiri bagi peserta didik karena mampu menyajikan visualisasi dengan bentuk-bentuk binatang sehingga memberikan kejutan dan kekaguman bagi peserta didik ketika membuka setiap halamannya (Khoiraton dkk dalam Meilia Safri, 2017: 108). Kelebihan dari fable adalah memberikan pengalaman khusus pada peserta didik karena melibatkan peserta didik seperti membaca, mendongeng, dan berperan menjadi tokoh binatang. Hal ini akan membuat kesan tersendiri kepada pembaca sehingga akan lebih mudah masuk ke dalam ingatan ketika belajar (Setyawan dkk dalam Meilia Safri, 2017:108).

Penggunaan fable dalam pembelajaran masih belum familiar dan banyak digunakan. Penyebabnya dikarenakan keterbatasan waktu dan kemampuan guru dalam mengembangkan bahan ajar berbentuk fable. Hal ini diketahui berdasarkan hasil wawancara dengan beberapa guru di SD kota padang dengan kriteria: 1) sekolah terakreditasi A dan 2) Guru mengalami kesulitan dalam mengembangkan materi pelajaran dikarenakan buku kurikulum 2013 yang digunakan dinilai terlalu sedikit memuat materi pelajaran. Metari pelajaran yang dipaparkan masih secara umum, sehingga guru harus mengembangkan bahan ajar sementara guru memiliki keterbatasan dalam mengembangkan bahan ajar, baik dari segi waktu maupun kemampuan untuk mengembangkannya.

Berdasarkan permasalahan di lapangan sesuai wawancara guru, wawancara siswa dan angket kebutuhan siswa, maka perlu dikembangkan bahan ajar yang sesuai dengan karakteristik siswa, menarik, dan interaktif, Salah satu solusi untuk permasalahan ini ialah dengan mengembangkan bahan ajar fabel. Buku ini dikembangkan dengan mengutamakan konten materi dan latihan soal yang memfasilitasi berkembangnya kemampuan membaca lancar permulaan siswa, memahami isi bacaan dengan baik dan keterampilan proses siswa. Untuk itu, peneliti bermaksud mengangkat penelitian ini dengan judul, "Pengembangan Bahan Ajar Membaca Permulaan dengan Menggunakan Buku Fabel di Kelas II".

\section{METODE}

Pendekatan pengembangan yang
digunakan mengacu pada Pendekatan 4-D,
Pendekatan ini dikembangkan oleh Sugiyono


(Sugiyono, 2013). Sugiyono (2009: 404) menjelaskan tahap-tahap Pendekatan 4-D antara lain: pendefinisian (define), perancangan (design), pengembangan (develop), dan penyebaran (disseminate). Akan tetapi, karena keterbatasan tenaga, biaya, dan waktu penulis, tahap penyebaran (disseminate) hanya dilakukan pada skala terbatas yaitu kelas II SDN 13 Lolong kota Padang yang sesuai dengan kebutuhan penulis.

Pendekatan pengembangan yang dipilih dalam setiap penelitian memiliki kelebihan yang dapat dijadikan sebagai dasar dan acuan dalam pemilihan Pendekatan yang dilakukan. Kelebihan yang dimiliki oleh Pendekatan 4-D antara lain: (1) lebih tepat digunakan sebagai dasar untuk pengembangan bahan ajar, (2) uraiannya terlihat lebih lengkap dan sistematis, dan (3) dalam pengembangannya melibatkan penilaian para ahli, sehingga sebelum dilakukan uji coba di lapangan bahan ajar telah dilakukan revisi berdasarkan penilaian, saran, dan masukan dari para ahli.

Tahap Pendefinisian ( Define). Tahap ini dilakukan dengan menganalisis tujuan dalam batasan materi pembelajaran yang dikembangkan. Tahap pendefinisian ini mendapatkan syarat-syarat pembelajaran yang sesuai dengan tujuan penelitian yaitu pengembangan bahan ajar membaca permulaan dengan menggunakan fabel. Terdapat tiga langkah yang dilakukan dalam tahap pendefinisian, yaitu:

Analisis kebutuhan disini merupakan analisis kebutuhan bahan ajar. Analisis bertujuan untuk mengetahui masalah dasar yang dibutuhkan dalam pengembangan bahan ajar. Analisis yang dilakukan pada bahan ajar melihat dua aspek utama, yaitu isi teks (content) dan desain (tampilan dan redaksi). Isi teks merupakan ketepatan dan keakuran informasi yang disajikan dalam teks. Sedangkan desain merupakan cara mengungkapkan dan menampilkan bahan sehingga mempunyai tingkat keterbacaan yang menarik dan memotivasi peserta didik.

Analisis peserta didik dilakukan dengan tujuan untuk mengetahui bahan ajar yang disukai peserta didik dengan memperhatikan karakteristik peserta didik. Karakteristik peserta didik yang ditelaah meliputi perkembangan bahasa, keterampilan membaca permulaan, dan latar belakang pengetahuannya. Analisis peserta didik diperlukan untuk mengidentifikasi tingkah laku dan karakteristik peserta didik agar memudahkan dalam menyusun dan merancang perencanaan dan bahan ajar yang akan digunakan dalam proses pembelajaran (Uno, 2007). Oleh sebab itu analisis peserta didik perlu dilakukan agar bahan ajar tematik yang dikembangkan sesuai dengan tingkah laku dan karakteristik peserta didik. Analisis ini dijadikan sebagai bahan acuan dalam mengembangkan bahan ajar membaca permulaan menggunakan fabel.

Analisis yang peneliti lakukan dengan melakukan observasi dan wawancara terhadap peserta didik terkait bahan ajar yang diinginkan. Berdasarkan hasil wawancara yang peneliti lakukan dengan beberapa peserta didik, mereka mengungkapkan bahwa bahan ajar yang digunakan kurang menarik bagi peserta didik.

Tahap perancangan adalah merancang buku cerita fabel di kelas II SD semester satu. Adapun hal-hal yang dirancang dalam pengembangan buku cerita fabel ini adalah :

a. Buku cerita fabel di rancang menggunakan kertas A4 dengan fullcolour.

b. Pemilihan teks fabel (teks sesuai dengan pembelajaran membaca permulaan).

c. Rancangan buku cerita fabel sesuai dengan tahapan proses membaca permulaan.

d. Cara penyajian tokoh yang berpengaruh dalam membaca permulaan anak.

Validitas dilakukan oleh ahli di bidang pembelajaran bahasa yang bertujuan untuk 
mendapatkan masukan terhadap keseluruhan isi materi yang terdapat dalam rancangan buku cerita fabel yang sudah dirancang. Selanjutnya divalidasi oleh ahli di bidang desain pembelajaran yang bertujuan untuk mendapatkan masukan mengenai kesesuaian isi teks cerita fabel yang yang dikembangkan untuk pembelajaran membaca permulaan di kelas II.

Ada dua macam validitas yang digunakan dalam pengembangan bahan ajar, yaitu:

1. Validitas isi (content validity), yaitu apakah buku cerita fabel yang dirancang sesuai dengan pembelajaran membaca permulaan.

2. Validitas konstruk (construct validity), yaitu kesesuaian komponen-komponen buku cerita fabel dengan unsur-unsur pengembangan yang sudah ditetapkan.

Bahan ajar yang digunakan merupakan bahan ajar yang telah divalidasi oleh validator. Uji praktikalitas bahan ajar dilakukan menggunakan angket dan lembar observasi.Observasi dilakukan oleh dua orang pengamat, yaitu guru dan peneliti sendiri. Observer mengamati keterpakaian bahan ajar dalam proses pembelajaran dan mengisi instrumen observasi yang telah disiapkan. observer mengisi angket keterpakaian bahan ajar fabel. Hasil angket ini dijadikan sebagai dasar untuk melakukan perbaikan terhadap bahan ajar yang dikembangkan. Aspek keterlaksanaan pembelajaran dilihat dari hasil pengisian lembar keterlaksanaan RPP oleh dua orang observer.

Efektivitas dilakukan untuk mengevaluasi bahan ajar telah efektif atau tidaknya. Halyang dilakukan dengan melihat aktivitas dari pembelajaran dan kemampuan membaca permulaan siswa.

Tahap ini merupakan tahap penggunaan bahan ajar yang telah dikembangkan pada subjek lain, misalnya di kelas lain, atau sekolah lain. Tujuannya adalah untuk menguji efektivitas penggunaan bahan ajar tersebut pada subjek yang berbeda. Bahan ajar yang dikatakan efektif jika dapat memberikan hasil yang baik terahadap hasil belajar siswa. Peneliti melakukan penyebaran bahan ajar tematik berbasis Turnamen dalam skala terbatas yaitu di kelas IV SDN 13 Lolong kota Padang.

\section{HASIL DAN PEMBAHASAN}

Validasi ahli isi/materi diperlukan sebagai suatu bentuk evaluasi terhadap isi/materi serta penyajian produk yang telah dikembangkan. Data yang diperoleh berupa data kuantitatif dan kualitatif melalui angket yang diberikan peneliti kepada ahli. Peneliti memberikan angket validasi isi/ materi, dan produk yang dikembangkan. Berdasarkan perhitungan data angket yang diperoleh dari validasi diperoleh sebesar 96,87\% dengan kategori sangat valid

Validasi bahasa diperlukan sebagai evaluasi terhadap bahasa yang digunakan dalam bahan ajar yang sudah dikembangkan. Penggunaan bahasa yang efektif dan komunikatif sangatlah penting dalam sebuah bahan ajar membaca permulaan. Validitas bahasa diberikan kepada ahli berupa angket yang menunjukkan perolehan 92.85 $\%$ dengan kategori sangat valid.

Validasi penyajian diperlukan sebagai evaluasi terhadap tampilan bahan ajar membaxa permulaan. Data yang diperoleh berupa data kuantitatif dan kualitatif melalui angket yang diberikan peneliti kepada ahli desain pembelajaran Berdasarkan perhitungan data angket yang diperoleh dari validasi ahli desain menunjukkan perolehan sebesar $93.75 \%$ dengan kategori sangat valid.

Validasi kegrafikaan diperlukan sebagai evaluasi terhadap kegrafikaan bahan ajar membaxa permulaan. Data yang diperoleh berupa data kuantitatif dan kualitatif melalui angket yang diberikan peneliti kepada ahli desain 
pembelajaran Berdasarkan perhitungan data angket yang diperoleh dari validasi ahli desain menunjukkan perolehan sebesar $90 \%$ dengan kategori sangat valid.

Validasi pembelajaran diperlukan sebagai evluasi terhadap rencana pelaksanaan pembelajaran. Validitas yang deiberikan kepada ahli berupa rpp dan angket, data yang di peroleh 85.91 dengan kategori valid.

Salah satu tujuan yang hendak dicapai dari penelitian ini yaitu memperoleh buku ajar keterampilan membaca permulaan dengan fabel di Kelas I SD yang praktis dan efektif. Setelah dinyatakan praktis dan efektif, kemudian dilakukan dalam kelompok kecil one to one kemudian dilanjutkan dengan small group kemudian dilakukan uji efektifitas bahan ajar.

Tingkat praktikalitas melihat sejauh mana peserta didik dapat menggunakan bahan ajar membaca permulaan fabel dengan baik. Pratikalitas yang diamati adalah keterlaksaan RPP, angket respon pendidik dan angket respon peserta didik terhadap pratikalitas bahan ajar. Hasil observasi saat uji coba di lapangan sesuai dengan perencanaan yang telah di buat dengan presentase $96.92 \%$ dengan kategori sangat praktis , sedangkan hasil angket dari respon pendidik memperoleh presentase $98.29 \%$, dengan kategori sangat praktis.dan hasil angket respon peserta didik memperoleh 96.15 dengan kategori sangat praktis. Hal ini menunjukkan bahwa bahan ajar membaca permulaan dalam tematik menggunakan fabel yang dikembangkan sangat praktis digunakan dalam proses pembelajaran membaca permulaan di kelas II SD.

Bahan ajar dikatakan efektif apabila memberikan efek atau pengaruh baik terhadap pencapaian tujuan bahan ajar yang dikembangkan. Efektivitas peserta didik dilihat dari hasil belajar peserta didik dalam proses membaca permulaan dengan model Vark. Hasil analisis data terhadap aktivitas peserta didik ketika proses pembelajaran dengan memperolah hasil 96.54\% dengan ketagori sangat tinggi, sedangkan hasil proses membaca permulaan memproleh $88.28 \%$ dengan kategori sangat tinggi. Sedangkan hasil keterampilan membaca permulaan dengan persentase $100 \%$ dengan katerogi sangat tinggi. Dari semua pengamatan aktivitas peserta didik, proses pembelajaran, sikap dan memberikan gambaran yang sangat baik dengan memperoleh presentase sangat tinggi, artinya penggunaan bahan ajar tematik membaca permulaan dengan fabel sangat layak dan efektif untuk disebarkan khususnya di kelas II SD. Hasil penelitan ini dapat dilihat pada tabel berikut 1 .

Tabel 1. hasil persentase bahan ajar

\begin{tabular}{|l|l|l|l|l|}
\hline No & \multicolumn{2}{|c|}{ Aspek } & $\begin{array}{l}\text { Pers } \\
\text { enas } \\
\text { e \% }\end{array}$ & Kategori \\
\hline 1 & $\begin{array}{l}\text { Valid } \\
\text { itas }\end{array}$ & Isi & $\begin{array}{l}96.8 \\
7\end{array}$ & $\begin{array}{l}\text { Sangat } \\
\text { valid }\end{array}$ \\
\hline & & Bahasa & $\begin{array}{l}92.8 \\
5\end{array}$ & $\begin{array}{l}\text { Sangat } \\
\text { valid }\end{array}$ \\
\hline & & Penyajian & $\begin{array}{l}93.7 \\
5\end{array}$ & $\begin{array}{l}\text { Sangat } \\
\text { valid }\end{array}$ \\
\hline & & Kegrafikaan & 90 & $\begin{array}{l}\text { Sangat } \\
\text { valid }\end{array}$ \\
\hline 2. & $\begin{array}{l}\text { Prati } \\
\text { kalita } \\
\text { s }\end{array}$ & $\begin{array}{l}\text { Keterlaksaan } \\
\text { RPP }\end{array}$ & $\begin{array}{l}96.9 \\
2\end{array}$ & $\begin{array}{l}\text { Sangat } \\
\text { praktis }\end{array}$ \\
\hline & & $\begin{array}{l}\text { Respon } \\
\text { pendidik }\end{array}$ & $\begin{array}{l}98.9 \\
2\end{array}$ & $\begin{array}{l}\text { Sangat } \\
\text { praktis }\end{array}$ \\
\hline & & $\begin{array}{l}\text { Respon peserta } \\
\text { didik }\end{array}$ & 96.1 & $\begin{array}{l}\text { Sangat } \\
\text { praktis }\end{array}$ \\
\hline 3 & $\begin{array}{l}\text { Efekt } \\
\text { ivitas }\end{array}$ & $\begin{array}{l}\text { Aktivitas } \\
\text { membaca }\end{array}$ & $\begin{array}{l}96.5 \\
4\end{array}$ & $\begin{array}{l}\text { Sangat } \\
\text { tinggi }\end{array}$ \\
\hline & & $\begin{array}{l}\text { Proses } \\
\text { membaca }\end{array}$ & $\begin{array}{l}88.2 \\
228\end{array}$ & $\begin{array}{l}\text { Sangat } \\
\text { tinggi }\end{array}$ \\
\hline & & $\begin{array}{l}\text { Membaca } \\
\text { permulaan }\end{array}$ & 100 & $\begin{array}{l}\text { Sangat } \\
\text { tinggi }\end{array}$ \\
\hline
\end{tabular}

\section{SIMPULAN}

Berdasarkan pengembangan dan uji coba dilakukan dilapangan terhadap bahan ajar membaca permulaan dengan fabel, bahwa pengembangan bahan ajar dari aspek validitas menunjukkan bahwa bahan ajar ini sangat valid 
360 Pengembangan bahan ajar membaca permulaan dengan menggunakan cerita fable pada siswa sekolah dasar- Reni Gustiawati, Darnis Arief, Ahmad Zikri

baik dari segi isi, bahasa, dan konstruk. Hasil validasi ini telah divalidasi oleh pakar dibidang masing-masing ahli dan sudah dikatakan sangat valid untuk digunakan. Sedangkan pratikalitas dikategorikan sangat praktis dilihat dari respon pendidik dan peserta didik. Hasil efektivitas peserta didik menunjukkan bahwa pengembangan bahan ajar membaca permulaan menggunakan fabel di kelas II SD telah dinyatakan efektif dan telah meningkatkan membaca permulaan, dan sangat layak digunakan.

\section{DAFTAR PUSTAKA}

Abidin, Y. (2012). Model Penilaian Otentik Dalam Pembelajaran Membaca Pemahaman Beroreintasi Pendidikan Karakter. Jurnal Pendidikan Karakter, 2(2), 164-178.

Amali, E. F., \& Tandyonomanu, D. (2015). Pengembangan Media Video Pembelajaran Pada Mata Pelajaran Seni Budaya Kompetensi Dasar Mengidentifikasi Jenis Musik Tradisi Dan Modern Nusantara Untuk Meningkatkan Hasil Belajar Siswa Belajar Kelas Xi Di Sma Negeri 1 Mengganti. Revista De Educación Laurus, 25(35), 103125.

Darma Aswita, Taufina, S. R. (2017). Development Of Teaching Material For Narrative Writing Using Graphic Organizer Story Map In Elementary School. International Journal of Research In Counseling And Education, 1(1), 22-26. Doi:10.24036/009za0002

Lestariningsih, N., \& Suardiman, S. P. (2017). Pengembangan Bahan Ajar TematikIntegratif Berbasis Kearifan Lokal Untuk Meningkatkan Karakter Peduli Dan Tanggung Jawab. Jurnal Pendidikan Karakter. Doi:10.21831/Jpk.V7i1.15503

Permendikbud. (2013). Sistem Pendidikan
Nasional. Permendikbud No. 20 Tahun 2013. Doi:10.16309/J.Cnki.Issn.10071776.2003.03.004

Prasetyo, Y. A. (2014). Ilustrasi Buku Cerita Fabel Sebagai Media Pendidikan Karakter Anak. Journal Of Visual Art, 3(1), 5-8. Retrieved From

Https://Journal.Unnes.Ac.Id/Sju/Index.Php/A rty/Article/View/2449

Rakhmawati, S., Muspiroh, N., Azmi, N., Pd, S. I., Tadris, J., Biologi, I., ... Cirebon, S. (2016).

Analisis Pelaksanaan Kurikulum 2013 berd

Ditinjau Dari Standar Proses Dalam Pembelajaran Biologi Kelas X Di Sma Negeri 1 Krangkeng. Scientiae Educatia: Jurnal Sains Dan Pendidikan Sains.

Rusdewanti, P. P., \& Gafur, A. (2017). Pengembangan Media Pembelajaran Interaktif Seni Musik Untuk Siswa Smp. Resital: Jurnal Seni Pertunjukan, 14(3), 153164. Doi:10.1103/Physrevlett.87.237401

Sudiasa, I. W., Rasna, I. W., Indriani, M. S., \& Hum, M. (2015). Kemampuan Menulis Cerita Fabel Dalam Pembelajaran Bahasa Indonesia Siswa Kelas Viii Smpn 6 Singaraja: Sebuah Kajian Struktur Gramatikal. Jurnal Jurusan Pendidikan Bahasa Dan Sastra Indonesia, 3(1).

Sugiyono. (2013). Metode Penelitian Pendidikan Pendekatan Kuantitaif, Kualitatif, Dan R\&D. Metode Penelitian Pendidikan Pendekatan Kuantitaif, Kualitatif, Dan R\&D. Doi:10.1007/S13398-014-0173-7.2

Taufina, M. (2017). Developing Literacy Reading Teaching Materials By Using Big Books As An Effort To Build The 2nd Grade Students' Characters In Elementary School. Atlantis Press, 118, 835-844. Doi:10.2991/Icset17.2017.136 